Article

\title{
A New Polyoxygenated Flavonol Gossypetin-3-O- $\beta$-D-Robinobioside from Caesalpinia gilliesii (Hook.) D. Dietr. and In Vivo Hepatoprotective, Anti-Inflammatory, and Anti-Ulcer Activities of the Leaf Methanol Extract
}

\author{
Mahmoud Emam ${ }^{1}\left(\mathbb{D}\right.$, Mohamed A. El Raey ${ }^{1, *}$, Alaadin E. El-Haddad ${ }^{2}$, Sally A. El Awdan ${ }^{3}$, \\ Abdel-Gawad M. Rabie ${ }^{4}$, Mohamed A. El-Ansari ${ }^{1}$, Mansour Sobeh ${ }^{5}$, Samir M. Osman ${ }^{2, *}$ \\ and Michael Wink $5, *$ D \\ 1 Department of Phytochemistry and Plant Systematics, National Research Centre, Dokki, Cairo 12622, Egypt; \\ mahmoudemamhegazy2020@gmail.com (M.E.); ansarialaa@hotmail.com (M.A.E.-A.) \\ 2 Department of Pharmacognosy, Faculty of Pharmacy, October 6 University, Cairo 12566, Egypt; \\ alaa_elhaddad.ph@o6u.edu \\ 3 Department of Pharmacology, National Research Centre, Dokki, Cairo 12622, Egypt; \\ sallyelawdan@ymail.com \\ 4 Department of Chemistry, Faculty of Science, Ain Shams University, Abbassia, Cairo 11566, Egypt; \\ Mohamed.abdelgawad@hotmail.com \\ 5 Department of Pharmaceutical Biology, Institute of Pharmacy and Molecular Biotechnology, Heidelberg \\ University, Im Neuenheimer Feld 364, 69120 Heidelberg, Germany; sobeh@uni-heidelberg.de \\ * Correspondence: ma.aziz@nrc.sci.eg (M.A.E.R.); samirosman@o6u.edu.eg (S.M.O.); \\ wink@uni-heidelberg.de (M.W.); Tel.: +49-6221-544880 (M.W.)
}

Academic Editor: Federica Pellati

Received: 15 November 2018; Accepted: 29 December 2018; Published: 31 December 2018

\begin{abstract}
A hitherto unknown polyoxygenated flavonol robinobioside (gossypetin-3-O- $\beta$-Drobinobioside) was isolated from the leaves of Caesalpinia gilliesii along with thirteen known phenolic secondary metabolites. The isolated compounds were characterized using spectroscopic analysis, including 1D and 2D NMR and mass spectrometry (MS) analyses. The extract reduced the level of liver damage in $\mathrm{CCl}_{4}$-induced liver injury in rats. A decrease of the liver biomarkers-aspartate aminotransferase (AST) and alanine aminotransferase (ALT) and an increase of total antioxidant capacity (TAC) levels-were observed similar to the liver protecting drug silymarin. In addition, the extract showed promising activity against carrageenan-induced paw edema in rats and protected their stomachs against ethanol-induced gastric ulcers in a concentration dependent fashion. The observed activities could be attributed to the high content of antioxidant polyphenols. Our results suggest that the $C$. gilliesii has the capacity to scavenge free radicals and can protect against oxidative stress, and liver and stomach injury.
\end{abstract}

Keywords: Caesalpinia gilliesii; flavonoids; anti-inflammatory; anti-ulcer; hepatoprotective activities

\section{Introduction}

Drug-induced liver injury is still a major challenge. Environmental toxicants, ingested metals, and some orally consumed drugs are renown causes of liver injury [1]. For instance, the uncontrolled use of non-steroidal anti-inflammatory drugs for the treatment of pain and inflammation carries the risk of liver toxicity as well as other serious adverse effects, such as peptic ulcers and gastrointestinal 
bleeding [2-4]. Thus, medicinal therapy is still in need for novel multi-functional approaches to tackle health problems and avoid or reduce adverse drug effects.

In this regard, plant secondary metabolites offer an interesting potential for pharmacological applications where they can serve as lead drugs in clinical trials for the treatment of various diseases [5]. The genus Caesalpinia, a member of the family Fabaceae (subfamily Caesalpinioideae) (148 genera, ca. 4400 species), comprises more than 500 species of tropical and subtropical trees and shrubs [6]. Many species of the genus Caesalpinia exhibit interesting biological activities and thus are used in folk medicine as antioxidant, anti-inflammatory, antimicrobial, anticancer, antidiabetic, hepatoprotective, and antiviral agents [7-10]. Plants of this genus produce flavonoids, steroids, triterpenoids, tannins, saponins, alkaloids, and terpenes [7-10].

The Yellow Bird of Paradise, Caesalpinia gilliesii (Hook.) D. Dietr, is native to Argentina and now is presently cultivated worldwide in the tropics and subtropics [6,11]. Recently, phenolics, fatty acids, and phytosterols were isolated from the flowers of $C$. gilliesii and the extract exhibited cytotoxic and hepatoprotective activities [11]. Moreover, the alcoholic extract of $C$. gilliesii leaves demonstrated substantial free radical scavenging activities in vitro [12].

In the present study, the hepatoprotective, anti-inflammatory, and anti-ulcer activities of the methanol extract from C. gilliesii leaves were evaluated in animal models. Further chromatographic analysis has led to the isolation of fourteen polyphenols, including one hitherto unknown, identified as gossypetin-3-O- $\beta$-D-robinobioside. The structure elucidation of all isolated compounds was done using spectroscopic analysis, including 1D and 2D NMR spectroscopy and mass spectrometry.

\section{Results}

\subsection{Phytochemical Composition}

The phytochemical analysis of the methanol extract from $C$. gilliesii leaves revealed a new flavonol robinobioside, namely gossypetin-3-O- $\beta$-D-robinobioside (11) together with thirteen known phenolic secondary metabolites, namely quercetin (1), quercetin-3-O- $\beta$-D-glucoside (2), quercetin-3-O- $\beta$-D-galactoside (3), rutin (4), quercetin-3-O- $\beta$-D-robinoside (5), kaempferol-3-O- $\beta$-Drutinoside (6), luteolin (7), luteolin-7-O- $\beta$-D-glucoside (8), isorhamnetin (9) [13-16], gossypetin-3-O- $\beta$-D-rutinoside (10) [16-19], $p$-hydroxybenzoic acid (12) [20], gallic acid (13) [21], and brevifolin carboxylic acid (14) [22]. The NMR data of compounds (1-10, 12-14) are shown in a supplementary file.

Compound (11) appeared as a yellow amorphous powder. In paper chromatography, the dark purple spot changed into a yellow color when exposed to ammonia vapor. The UV spectral data of this compound exhibited pronounced major absorption bands at $\lambda_{\max }=352$ and $261 \mathrm{~nm}$, corresponding to band I and band II of flavonoids, respectively, which confirmed the highly oxygenated flavonol nature with 3-hydroxyl substituent [13]. Moreover, MS/MS spectrum showed a quasi-molecular ion $[\mathrm{M}-\mathrm{H}]^{-}$at $m / z 625$, and different fragments at $m / z 317[\mathrm{M}-\mathrm{H}-\text { rhamnohexose }]^{-}$, $457\left[\mathrm{M}-\mathrm{H}-\text { rhamnohexose }-\left(1,3 \mathrm{~A}_{\mathrm{o}}-\mathrm{B}_{\mathrm{o}}\right)\right]^{-}$, and $489\left[\mathrm{M}-\mathrm{H}-\left(0,2 \mathrm{~A}^{+}-\mathrm{B}^{+}\right)\right]^{-}$, as shown in Figure 1. In addition, the ${ }^{1} \mathrm{H}-\mathrm{NMR}$ spectrum displayed aromatic proton signals, appearing as doublet at $\delta 7.76 \mathrm{ppm}$ corresponding to $\mathrm{H}-2^{\prime}$ and doublet of doublet at $7.67 \mathrm{ppm}$ to $\mathrm{H}-6^{\prime}$ that was stereo chemically meta-coupled with $\mathrm{H}-2^{\prime}$ and ortho-coupled with $\mathrm{H}-5^{\prime}$, which appeared as doublet signal with $J=8.5 \mathrm{~Hz}$ at $\delta 6.79 \mathrm{ppm}$. The compound had C-8 substitution indicated by the disappearance of $\mathrm{H}-8$ signal and the appearance of singlet signal at $\delta 6.14$ corresponding to $\mathrm{H}-6$. The attached proton test (APT NMR) showed different chemical shifts of carbon signals such as $C-4$ at $\delta 177.76$, oxygenated $S p^{2}$ carbons C-2, C-3, C-5, C-7, C-8, C-9, C- $3^{\prime}$, and C- $4^{\prime}$ at $\delta 156.16,133.09,158.83,153.8,122.6,148.47$, 144.78 , and 148.42, respectively. The downfield shift of C-8 signal to $122.6 \mathrm{ppm}$ indicated that the substitution was at position-8. Moreover, the upfield shift of C-3 signal at $\delta 133.09 \mathrm{ppm}$ confirmed the glycosidic linkage with aglycone at position C-3. On the other hand, $S p^{2}$ carbon signals appeared at $\delta 98.39,103.5,121.53,115.1,116.2$, and 121.65 assigned for C-6, C-10, C-1', C-2', C-5', and C-6', 
respectively. The structure of the aglycone was deduced to be gossypetin in agreement with previous published data [16-18]. Two anomeric sugar protons were also observed in ${ }^{1} \mathrm{H}-\mathrm{NMR}$ spectrum at $\delta 5.35$ $\left(\mathrm{d}, J=7.7 \mathrm{~Hz}, \mathrm{H}-\mathrm{1}^{\prime \prime}\right)$ and 4.45 (br. s, $\left.\mathrm{H}-1^{\prime \prime \prime}\right)$, indicating that compound (11) is a diglycoside. One sugar unit was elucidated as terminal rhamnose unit confirmed by $\mathrm{H}-1^{\prime \prime \prime}$ broad singlet at $\delta 4.45$ and the doublet signal of the methyl protons of rhamnose $\left(3 \mathrm{H}-6^{\prime \prime \prime}\right)$ with $J=6.2 \mathrm{~Hz}$ at $\delta 1.08$. The rhamnose unit was directly attached to the hexose sugar unit.

The anomeric carbon signals of di-sugars, appearing at $\delta 102.36$ and 100.43, were assigned to $C-1^{\prime \prime}$ hexose and $C-1^{\prime \prime \prime}$ rhamnose, respectively. The other carbon signals of hexose sugar could reveal a galactoside (Table 1 ) in agreement with reported data $[16,19]$. To confirm the nature of the sugar moieties, the compound was subjected to complete acid hydrolysis with $2 \mathrm{~N} \mathrm{HCl}$ for $3 \mathrm{~h}$ and the hydrolysis products were identified on paper chromatographyas galactose and rhamnose when compared to authentic sugar samples [13].

The structure confirmation of compound (11) was achieved by 2D NMR spectroscopy, including an $\mathrm{HH}$ COSY (homonuclear correlated spectroscopy) experiment that showed cross peaks for the adjacent protons (neighboring protons), an HSQC (heteronuclear single quantum coherence spectroscopy) experiment that showed direct attachment between the proton and its carbon, and the interglycosidic linkage by HMBC (heteronuclear multiple bond correlation) (Figure 1).
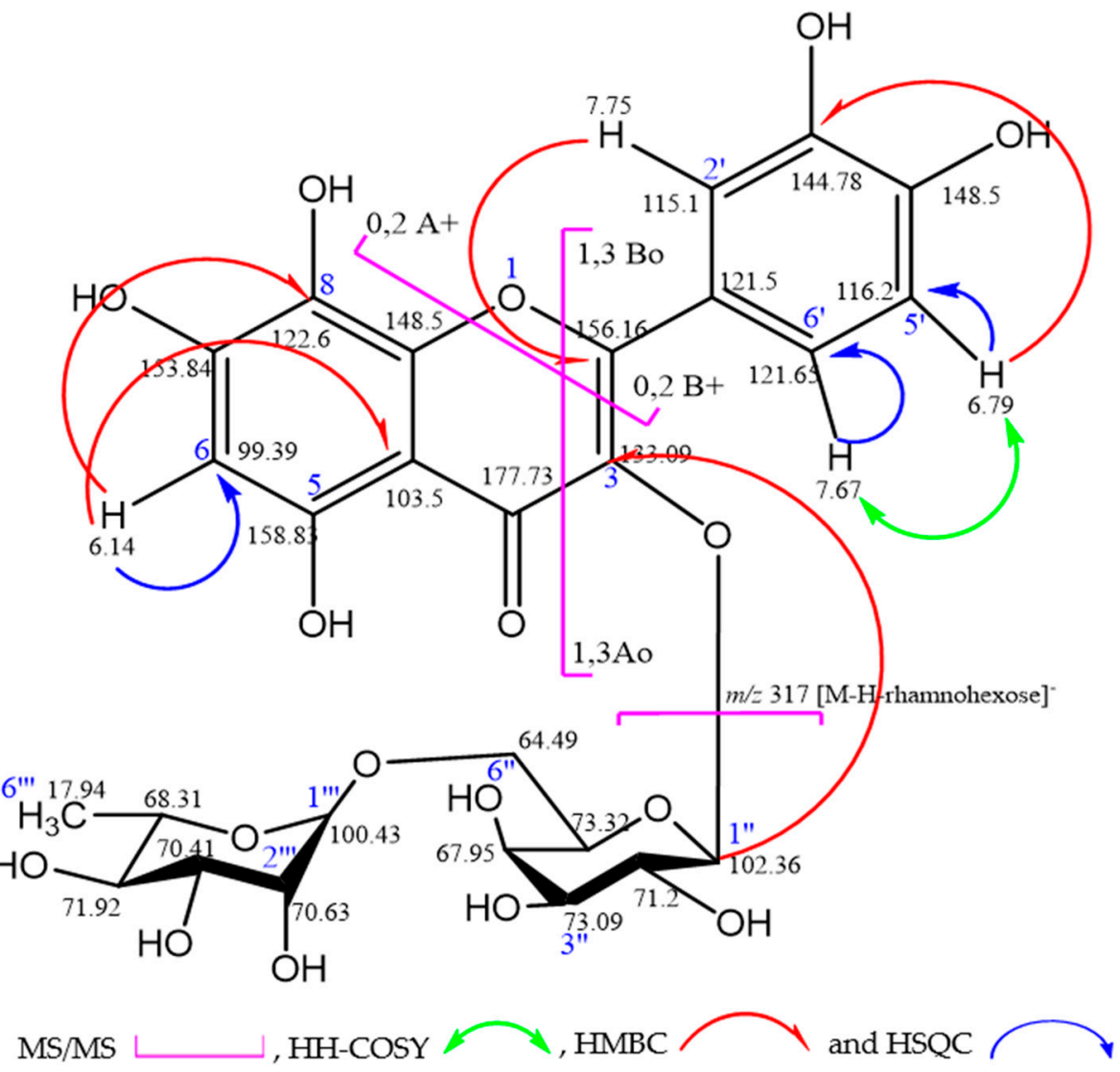

Figure 1. Selected fragmentation pattern (MS/MS) and correlations of gossypetin-3-O- $\beta$-D-robinobioside.

Therefore, the compound was identified as gossypetin-3-O- $\beta$-D-robinobioside [rhamnosyl $(1 \rightarrow 6)$ galactoside] with a molecular formula of $\mathrm{C}_{27} \mathrm{H}_{30} \mathrm{O}_{17}$. This is the first report of the isolation and identification of such compound in nature. The spectral data of the compound are shown in the supplementary file (Figures S1-S6). 
Table 1. ${ }^{1} \mathrm{H}$ and APT-NMR data and HMBC correlations for compound (11) (gossypetin-3-O- $\beta$-Drobinobioside [rhamnosyl $(1 \rightarrow 6)$ galactoside] $)$ recorded in DMSO- $d_{6} ; \delta$ in ppm, $J$ in $\mathrm{Hz}$.

\begin{tabular}{|c|c|c|c|c|}
\hline Position & APT & $\delta_{H}(\mathrm{mult}, J[\mathrm{~Hz}])$ & $\delta_{C}$ & HМBC $(\mathrm{H} \rightarrow \mathrm{C})$ \\
\hline 2 & $\mathrm{C}$ & & 156.16 & \\
\hline 3 & $\mathrm{C}$ & & 133.09 & \\
\hline 4 & $\mathrm{C}$ & & 177.73 & \\
\hline 5 & $\mathrm{C}$ & & 158.83 & \\
\hline 6 & $\mathrm{CH}$ & $6.14(1 \mathrm{H}, \mathrm{s}, \mathrm{H}-6)$ & 98.39 & $C(8), C(10)$ \\
\hline 7 & $\mathrm{C}$ & & 153.84 & \\
\hline 8 & $\mathrm{C}$ & & 122.6 & \\
\hline 9 & $\mathrm{C}$ & & 148.5 & \\
\hline 10 & C & & 103.50 & \\
\hline $1^{\prime}$ & $\mathrm{C}$ & & 121.50 & \\
\hline $2^{\prime}$ & $\mathrm{CH}$ & $7.75\left(1 \mathrm{H}, \mathrm{d}, J=2.0 \mathrm{~Hz}, \mathrm{H}-2^{\prime}\right)$ & 115.10 & $\mathrm{C}(2), \mathrm{C}\left(4^{\prime}\right), \mathrm{C}\left(6^{\prime}\right)$ \\
\hline $3^{\prime}$ & $\mathrm{C}$ & & 144.78 & \\
\hline $4^{\prime}$ & $\mathrm{C}$ & & 148.50 & \\
\hline $5^{\prime}$ & $\mathrm{CH}$ & $6.79\left(1 \mathrm{H}, \mathrm{d}, J=8.5 \mathrm{~Hz}, \mathrm{H}-5^{\prime}\right)$ & 116.2 & $C\left(1^{\prime}\right), C\left(3^{\prime}\right)$ \\
\hline $6^{\prime}$ & $\mathrm{CH}$ & $7.67\left(1 \mathrm{H}, \mathrm{dd}, J=2 \& 8.5 \mathrm{~Hz}, \mathrm{H}-6^{\prime}\right)$ & 121.65 & $C(2), C\left(2^{\prime}\right), C\left(4^{\prime}\right)$ \\
\hline $1^{\prime \prime}$ & $\mathrm{CH}$ & $5.35\left(1 \mathrm{H}, \mathrm{d}, J=7.7 \mathrm{~Hz}, \mathrm{H}-1^{\prime \prime}\right)$ & 102.36 & \\
\hline $2^{\prime \prime}$ & $\mathrm{CH}$ & & 71.20 & \\
\hline $3^{\prime \prime}$ & $\mathrm{CH}$ & & 73.09 & \\
\hline $4^{\prime \prime}$ & $\mathrm{CH}$ & & 67.95 & \\
\hline $5^{\prime \prime}$ & $\mathrm{CH}$ & & 73.32 & \\
\hline $6^{\prime \prime}$ & $\mathrm{CH}_{2}$ & & 64.79 & \\
\hline $1^{\prime \prime \prime}$ & $\mathrm{CH}$ & 4.45 (1H, br.s, $\left.\mathrm{H}-1^{\prime \prime \prime}\right)$ & 100.43 & \\
\hline $2^{\prime \prime \prime}$ & $\mathrm{CH}$ & & 70.63 & \\
\hline $3^{\prime \prime \prime}$ & $\mathrm{CH}$ & & 70.41 & \\
\hline $4^{\prime \prime \prime}$ & $\mathrm{CH}$ & & 71.92 & \\
\hline $5^{\prime \prime \prime}$ & $\mathrm{CH}$ & & 68.31 & \\
\hline $6^{\prime \prime \prime}$ & $\mathrm{CH}_{3}$ & $1.08\left(3 \mathrm{H}, \mathrm{d}, J=6.2 \mathrm{~Hz}, \mathrm{H}-6^{\prime \prime \prime}\right)$ & 17.94 & \\
\hline
\end{tabular}

\subsection{Hepatoprotective Activity}

After $\mathrm{CCL}_{4}$ injection (on day 8), a significant elevation in the liver biomarkers aspartate aminotransferase $(A S T)(U / L)$ and alanine aminotransferase $(A L T)(U / L)$ was observed in the $C_{C L}$ group compared to the control group. Rats pretreated with the silymarin (a flavonolignan from Silybum marianum) were apparently protected against liver injury when compared to the $\mathrm{CCl}_{4}$ group $(p<0.01)$ (Figure 2). Also, $\mathrm{CCl}_{4}$ administration led to a significant decrease $(p<0.01)$ in TAC $(\mu \mathrm{mole} / \mathrm{L})$ compared to the control group. Pretreatment of rats with the methanol extract significantly increased $(p<0.01)$ the level of total antioxidant capacity (TAC) compared to the $\mathrm{CCl}_{4}$ treated group. Also, pretreatment with the methanol extract resulted in a significant decrease in the enzyme levels, which indicates a protection of hepatic tissue damage caused by $\mathrm{CCl}_{4}$ (Figure 2). The significant hepatoprotective activity of the methanol extract may be attributed to its high content of polyphenols and their antioxidant activities [12].

\subsection{Histopathological Investigation}

Histopathological observations on organ morphology confirmed the biochemical analyses. Normal hepatocytes are shown in Figure 3a. In the $\mathrm{CCL}_{4}$ group, the liver sections showed a loss of cellular architecture, marked degenerative changes, enlarged nuclei, cell infiltration with clear pyknotic reaction, and dilated liver sinusoids, as well as other nuclear changes (karyolysis and karyorrhexis) (Figure 3b). Silymarin pretreatment resulted in moderate cellular degeneration with more or less normal hepatocytes (Figure 3c). Rats pretreated with methanol extract showed mild nuclear changes and apoptosis, mild necrotic changes and normal appearance of Kupffer cells, and mild dilatation of liver sinusoids with normal tissue histological-architecture (Figure 3d). 

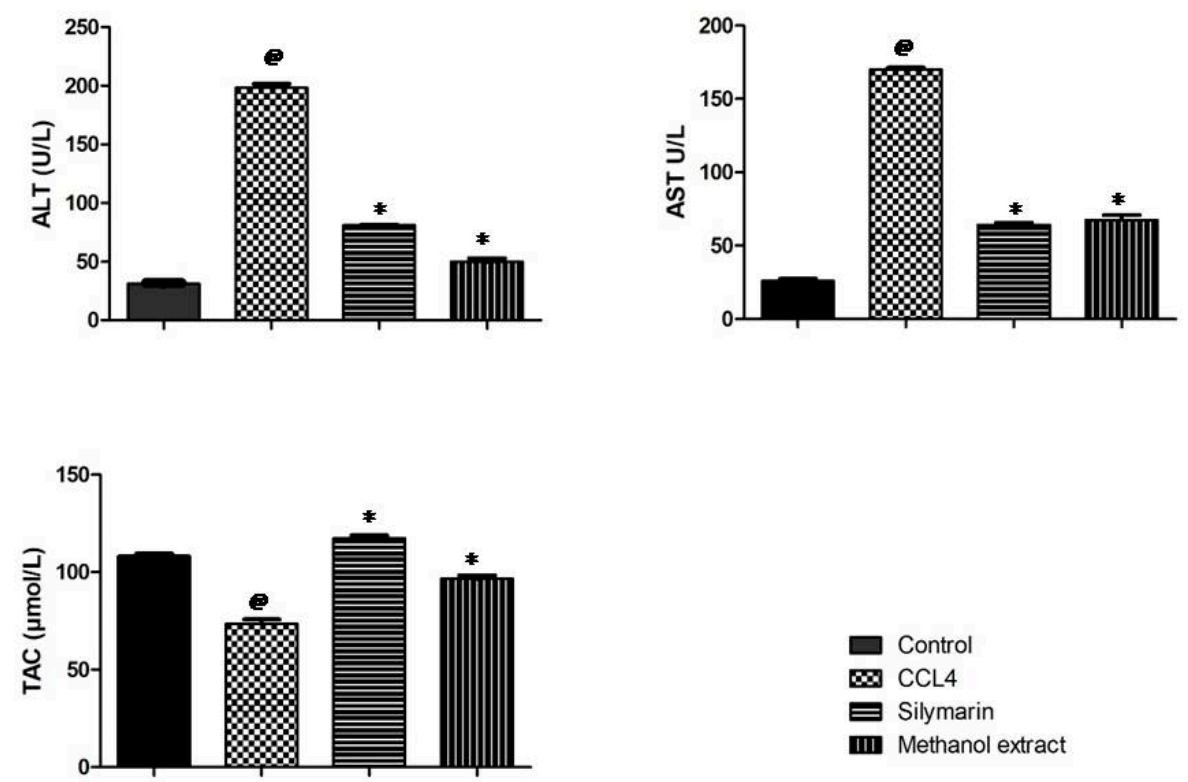

Figure 2. Hepatoprotective effect of Caesalpinia gilliesii leaves on liver biomarkers in $\mathrm{CCl}_{4}$-induced hepatotoxicity in rats $(n=6) .{ }^{\circledR} p<0.01$ vs control group. ${ }^{*} p<0.01 \mathrm{vs} \mathrm{CCl}_{4}$ group.

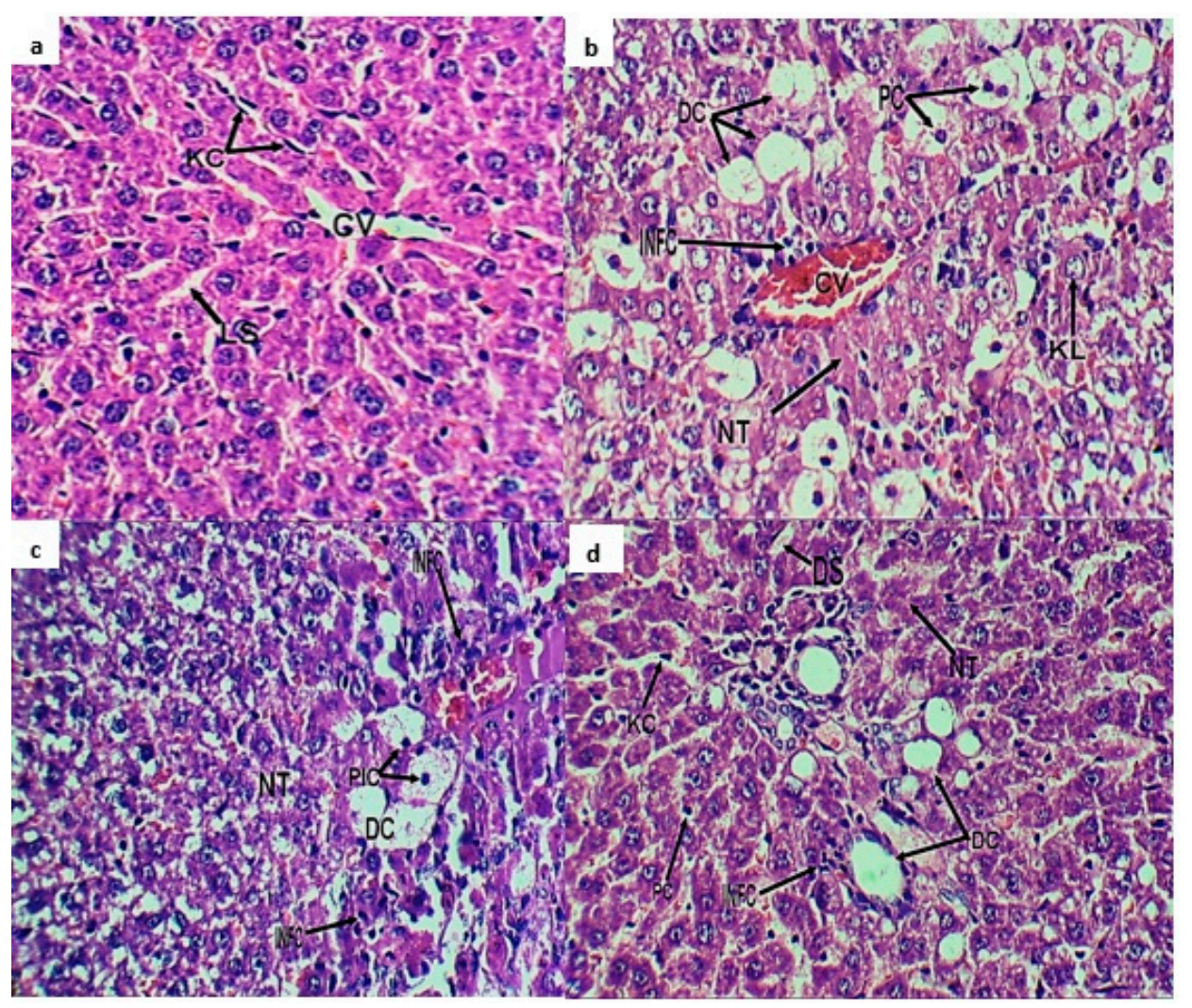

Figure 3. Photomicrograph of liver sections (a) normal liver with normal hepatocytes, normal hepatic cords and normal distribution of Kupffer cells (KC) with normal liver sinusoids (LS); (b) $\mathrm{CCL}_{4}$ group showed marked infiltration of inflammatory cells (INF), marked degenerative changes, necrotic tissue (NT), and degenerated cells (DC) with clear pyknotic reaction (PC); (c) silymarin group showed moderate hepatocyte degeneration; (d) methanol extract group exhibited mild nuclear changes and apoptosis, mild necrotic changes, normal appearance of Kupffer cells, and mild dilatation of liver sinusoids with normal tissue histological-architecture. Central vein (CV), infiltration of inflammatory cells (INFC), karyolysis (KL), pyknotic changes (PIC), and dilated liver sinusoids (DS). 


\subsection{Anti-Inflammatory Activity: Carrageenan-Induced Edema Assay}

The carrageenan injection resulted invisible redness and pronounced edema in the hind paws of rats after $4 \mathrm{~h}$ [23]. Indomethacin, a well-known non-steroidal anti-inflammatory drug, significantly decreased carrageenan-induced edema (in agreement with many studies) [24]. Oral administrations of the methanol extract (100 and $200 \mathrm{mg} / \mathrm{kg}$ ) one hour before induction of inflammation significantly $(p<0.05)$ reduced the edema volume at all-time points (Figure 4$)$.

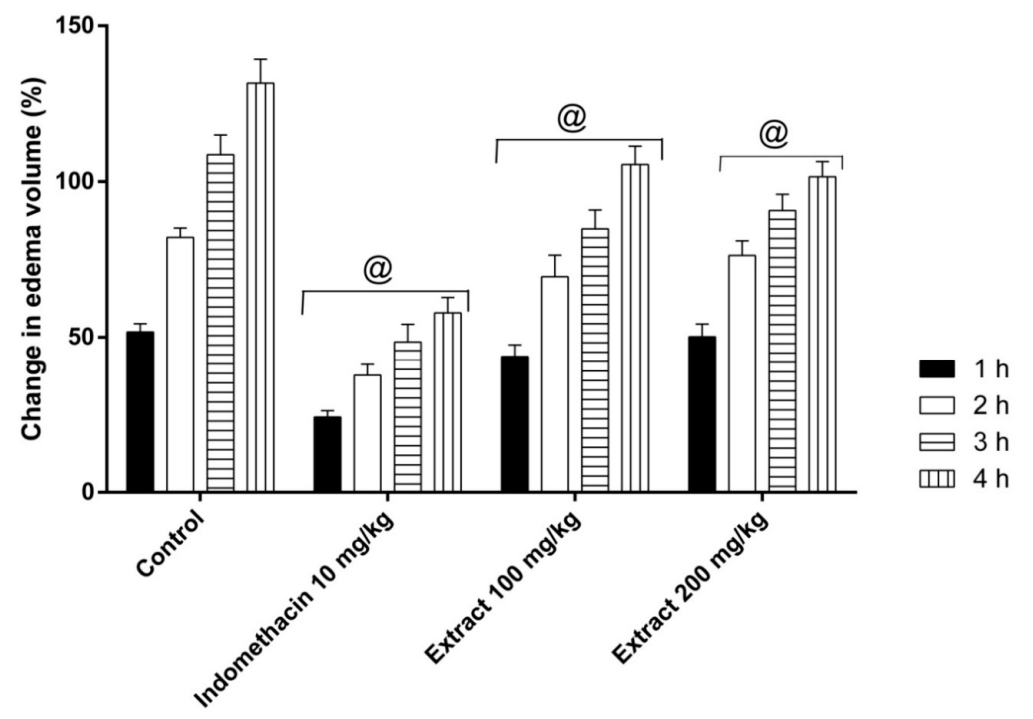

Figure 4. Anti-inflammatory protective effect of $C$. gilliesii leaves on carrageenan-induced inflammation in rats. The data are represented as means $\pm \mathrm{SE} .{ }^{\circledR} p<0.05$ vs control group.

\subsection{Anti-Ulcer Activity}

The oral administration of ethanol increases the acid content in stomach, which in turn may induce acute gastric lesions. The ethanol model has been widely used to explore the gastro protective effects [25,26]. Pretreatment with the methanol extract (100 and $200 \mathrm{mg} / \mathrm{kg}$ ) decreased the number of lesions and reduced ulcer severity values $(p<0.05)$ compared to the control ethanol group (Figure 5). These results can probably be attributed to the inhibition of gastric acid secretion or the inhibition of lipid peroxidation by the antioxidant phenolics in the extract [12].

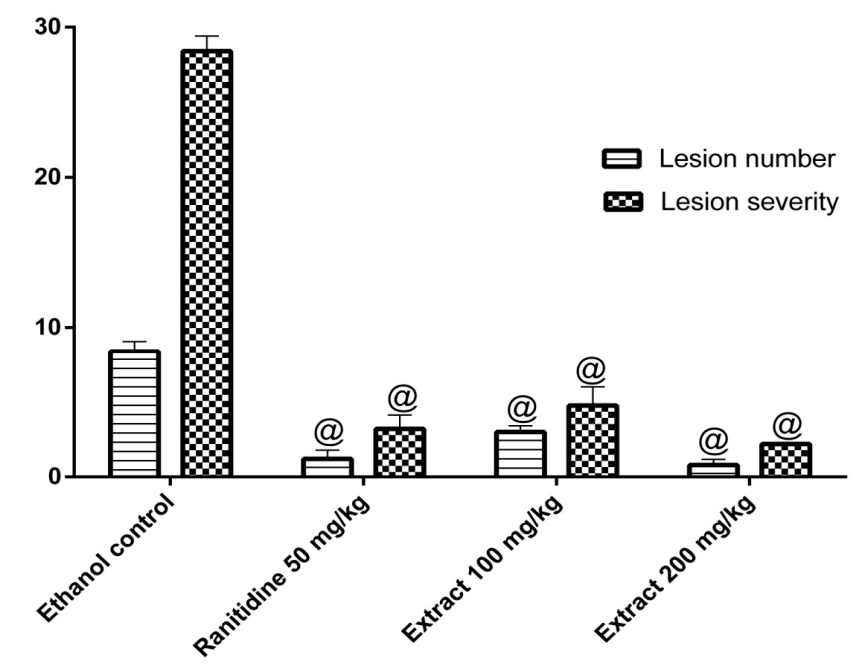

Figure 5. Anti-ulcer effects of the methanol extract of $C$. gilliesii leaves $(n=6)$. Statistical analysis was performed by Kruskal-Wallis non-parametric one way ANOVA followed by Mann Whitney multiple comparisons test. ${ }^{\circledR} p<0.05$ vs control ethanol group. 


\section{Discussion}

In this study, 14 phenolic secondary metabolites were isolated from the methanol extract of $C$. gilliesii leaves by column chromatography and characterized using conventional and spectroscopic analyses. Out of the isolated compounds, a new gossypetin-3-O- $\beta$-D-robinobioside [rhamnosyl $(1 \rightarrow 6)$ galactoside] was characterized. Other compounds such as quercetin and rutin $[27,28]$, luteolin [29], isorhamnetin [30], gallic acid [28], and brevifolin carboxylic acid [21] were previously described in the genus. On the other hand, $p$-hydroxybenzoic acid, quercetin-3-O- $\beta$-D-glucoside, quercetin-3-O- $\beta$-galactoside, quercetin-3-O- $\beta$-D-robinoside, kaempferol-3-O- $\beta$-D-rutinoside, luteolin-7-O- $\beta$-D-glucoside, and gossypetin-3-O- $\beta$-D-rutinoside were isolated from the genus for the first time. Based on HPLC analysis, quercetin-3-O- $\beta$-D-glucoside, quercetin-3-O- $\beta$-D-galactoside, quercetin-3-O- $\beta$-D-robinoside, kaempferol-3-O- $\beta$-D-rutinoside, luteolin-7-O- $\beta$-D-glucoside, and rutin dominated in the extract (HPLC chromatogram is shown in Figure S7).

Reactive oxygen species (ROS) are involved in the development of several health disorders, among them liver injury. $\mathrm{CCl}_{4}$ induces severe hepatic injury with a multivariate damage, and among them are free radicals propagations [31]. In the current study, the methanol extract counteracted the deleterious effects of $\mathrm{CCl}_{4}$ induced liver injury in rats (reduction of ALT, AST and increase of TAC). Also, the extract protected the liver architecture against the pathologic effects of $\mathrm{CCl}_{4}$ at a dose of $300 \mathrm{mg} / \mathrm{kg}$. These activities might be attributed to the high content of polyphenolic compounds such as quercetin-3-O- $\beta$-D-glucoside, quercetin-3-O- $\beta$-D-galactoside, rutin, kaempferol-3-O- $\beta$-D-rutinoside, and luteolin-7-O- $\beta$-D-glucoside. Similar activities were reported from $C$. gilliesii flowers and other Caesalpinia species $[11,32,33]$.

The acute inflammation model; carrageenan-induced paw edema, is widely used for assessing anti-inflammatory candidates [34]. Oral administration of C. gilliesii leaves methanol extract significantly diminished carrageenan-induced paw edema in rats in the two dose levels (100 and $200 \mathrm{mg} / \mathrm{kg}$ ). Flavonoids along with their glycosides, such as kaempferol, apigenin, luteolin, myricetin, and quercetin, possess anti-inflammatory effects $[35,36]$. These results are in agreement with those reported from Caesalpinia pulcherrima and others [33,37].

Ethanol-induced ulcer is a well-defined model to evaluate the gastroprotective activities of plant extracts. Ethanol induces oxidative stress, reduces gastric blood flow, and exerts a direct toxic effect on the epithelium forming necrotic lesions [38]. The current work showed that administration of C. gilliesii leaves methanol extract exhibited substantial gastroprotective properties; it diminished ulcer numbers and ulcer severity in a dose-dependent fashion after ethanol challenge. These activities might be attributed to the presence of antioxidant polyphenolics. Similar activities were reported from other Caesalpinia species, namely C. pulcherrima, C. sappan, C. crista, and C. bonduc [32,37-40].

The hepatoprotective and anti-inflammatory activities are in agreement with those reported from extracts rich in polyphenols such as Eremophila maculata, Syzygium jambos, Syzygium aqueum, and Syzygium samarangense [31,34,41,42]. To sum up, C. gilliesii counteracts oxidative stress in several animal models and exhibits noticeable hepatoprotective, anti-inflammatory, and anti-ulcer activities.

\section{Material and Methods}

\subsection{Plant Material}

Leaves of C. gilliesii were collected in May 2015 from the Borg El Arab region, Egypt. The plant was taxonomically identified and kept under the accession number M-130 at the CAIRC Herbarium of the National Research Centre (NRC), Cairo, Egypt [43].

\subsection{Extraction and Isolation}

C. gilliesii leaves were washed with distilled water and then dried in shade. Dried leaves $(2 \mathrm{~kg})$ were powdered and macerated with $70 \%(v / v)$ aqueous methanol. After solvent evaporation under reduced pressure (Rotavapor ${ }^{\circledR}$ R-300, BÜCHI, Flawil, Switzerland), a portion of the total crude extract 
$(60 \mathrm{~g})$ was suspended in $500 \mathrm{~mL}$ of distilled water, sonicated $(30 \mathrm{~min})$, and defatted using $n$-hexane $(5 \times 1 \mathrm{~L})$. After the removal of then-hexane layer $(2.85 \mathrm{~g})$, the extract was lyophilized and then extracted with methanol (25 g). The latter was applied to a HP-20 Diaion ${ }^{\circledR}$ (Sigma Aldrich, CA, USA) column chromatography. Chromatography started with $100 \% \mathrm{H}_{2} \mathrm{O}$ and the polarity was decreased gradually with methanol (10\% up to $100 \%)$. Fractions were collected and analytical paper chromatography and two-dimensional paper chromatography were used to identify the subfractions. Further purification of the fractions over Sephadex LH-20 columns (Pharmacia, Uppsala, Sweden) (using 50\% methanol and butane: water 1:1; upper layer) and preparative paper chromatography (Whatman 3MM $46 \times 57 \mathrm{~cm}$ ) were used to separate and purify the isolated compounds.

\subsection{Experimental Analysis}

NMR spectroscopy (Varian, CA, USA), 300, 400 and $500 \mathrm{MHz}$ ): samples (10 mg/each) were dissolved in deuterated DMSO- $d_{6}$ or $\mathrm{CD}_{3} \mathrm{OD}$. LC-MS/MS mass spectra were recorded on a ThermoFinnigan (Thermo Electron Corporation, Austin, TX, USA) LC system coupled with the mass spectrometer (LCQ-Duo ion trap) having a (ThermoQuest, Thermo Scientific, Waltham, MA, USA) ESI source. A Silica gel C18 reversed-phase column (Zorbax Eclipse XDB-C18, Rapid resolution, $4.6 \times 150 \mathrm{~mm}, 3.5 \mu \mathrm{m}$, Agilent, Santa Clara, CA, USA) was utilized [44]. UV measurements: UV/vis spectra were recorded on a Shimadzu model UV-240 spectrophotometer (Shimadzu, Tokyo, Japan) at $\mathrm{UV}\left(\lambda_{\text {range }}=240: 460 \mathrm{~nm}\right)$.

Compound (11) was identified on the basis of 1D, 2D-NMR, and MS analysis as gossypetin-3-O- $\beta$-D-robinobioside [rhamnosyl $(1 \rightarrow 6)$ galactoside]: a yellow amorphous powder (22 mg) (UV $\left.\lambda_{\max }=261,352 \mathrm{~nm}\right) .{ }^{1} \mathrm{H}-\mathrm{NMR}\left(500 \mathrm{MHz}, \mathrm{DMSO}-d_{6}\right): \delta 12.62(1 \mathrm{H}$, br.s, 5-OH), $7.75\left(1 \mathrm{H}, \mathrm{d}, J=2.0 \mathrm{~Hz}, \mathrm{H}-2^{\prime}\right), 7.67\left(1 \mathrm{H}, \mathrm{dd}, J=2 \& 8.5 \mathrm{~Hz}, \mathrm{H}-6^{\prime}\right), 6.79\left(1 \mathrm{H}, \mathrm{d}, J=8.5 \mathrm{~Hz}, \mathrm{H}-5^{\prime}\right)$, $6.14(1 \mathrm{H}, \mathrm{s}, \mathrm{H}-6), 5.35\left(1 \mathrm{H}, \mathrm{d}, J=7.7 \mathrm{~Hz}, \mathrm{H}-1^{\prime \prime}\right), 4.45\left(1 \mathrm{H}\right.$, br.s, $\left.\mathrm{H}-1^{\prime \prime \prime}\right), 1.08\left(3 \mathrm{H}, \mathrm{d}, J=6.2 \mathrm{~Hz}, \mathrm{H}-6^{\prime \prime \prime}\right)$. APT-NMR (125.721 MHz, DMSO-d $d_{6}$ ): $\delta 156.16$ (C-2), 133.09 (C-3), 177.73 (C-4), 158.83 (C-5), 98.39 (C-6), 153.84 (C-7), 122.6 (C-8), 148.5 (C-9), 103.50 (C-10), $121.50\left(\right.$ C-1 $\left.^{\prime}\right), 115.10\left(\mathrm{C}-2^{\prime}\right), 144.78$ (C-3'), 148.50 (C-4'), $116.2\left(\mathrm{C}-5^{\prime}\right), 121.65\left(\mathrm{C}-6^{\prime}\right), 102.36\left(\mathrm{C}-1^{\prime \prime}\right), 71.20\left(\mathrm{C}-2^{\prime \prime}\right), 73.09\left(\mathrm{C}-3^{\prime \prime}\right), 67.95\left(\mathrm{C}-4^{\prime \prime}\right), 73.32\left(\mathrm{C}-5^{\prime \prime}\right), 64.79\left(\mathrm{C}-6^{\prime \prime}\right)$, $100.43\left(\mathrm{C}-1^{\prime \prime \prime}\right), 70.63\left(\mathrm{C}-2^{\prime \prime \prime}\right), 70.41\left(\mathrm{C}-3^{\prime \prime \prime}\right), 71.92\left(\mathrm{C}-4^{\prime \prime \prime}\right), 68.31\left(\mathrm{C}-5^{\prime \prime \prime}\right), 17.94\left(\mathrm{C}-6^{\prime \prime \prime}\right)$. ESI-MS/MS

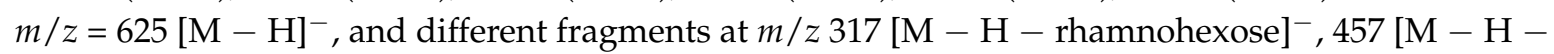
rhamnohexose $\left.-\left(1,3 \mathrm{~A}_{\mathrm{o}}-\mathrm{B}_{\mathrm{o}}\right)\right]^{-}$and $489\left[\mathrm{M}-\mathrm{H}-\left(0,2 \mathrm{~A}^{+}-\mathrm{B}^{+}\right)\right]^{-}$.

\subsection{Biological Experiments}

\subsubsection{Drugs and Chemicals}

Silymarin (CID Co., Giza, Egypt), carbon tetrachloride, (E. Merck (I) Ltd., Mumbai, India), olive oil, carrageenan lambda (Sigma Aldrich, Steinheim, Germany), indomethacin (Kahira, Pharmaceuticals Co. Cairo, Egypt) and ranitidine (Pharco Pharmaceuticals Co. Alexandria, Egypt) were used. TAC and kits were used for the liver biomarkers; ALT and AST were purchased from Biodiagnostics Co. (Cairo, Egypt). All other chemicals were of analytical grade.

\subsubsection{Animals}

Mature male albino Wister rats (160 $\pm 10 \mathrm{~g}, 10-12$ weeks age) were obtained from the National Research Centre, Giza, Egypt. Animals were acclimatized to our laboratory environment prior to the experiments for 7 days and housed in colony cages ( 6 rats per cage) with normal light/dark cycles at temperatures of $25 \pm 2{ }^{\circ} \mathrm{C}$ and free access to standard food and water. All experimental procedures and animal care methods in this study were approved by the Ethical Committee of the National Research Centre and followed the recommendations of the National Institute of Health Guide for Care and Use of Laboratory Animals (NIH1985). 


\subsubsection{Hepatoprotective Activity}

Four groups of rats ( 6 rats each) were treated as follows: control group and $\mathrm{CCL}_{4}$ group rats were fed on vehicle; silymarin group rats received $100 \mathrm{mg} / \mathrm{kg}$ silymarin p.o. once daily; methanol extract group rats received $300 \mathrm{mg} / \mathrm{kg}$ extract p.o. once daily. Silymarin and the methanol extract were administered in the morning by the gavage method. On day 7 , the rats (except control) obtained a single intraperitoneal injection of $30 \% \mathrm{CCL}_{4}$ in olive oil $(1 \mathrm{~mL} / \mathrm{kg})$. On day 8 , i.e., $24 \mathrm{~h}$ after $\mathrm{CCL}_{4}$ injection, blood was collected in centrifuge tubes from the rats of all groups [45]. AST and ALT were quantified using the kits described by the manufacturers. Also, TAC was estimated by ferric reducing antioxidant power (FRAP) assay [46]. The enzyme activity was expressed as units/liter (U/L).

\subsubsection{Histopathological Investigation}

After blood sampling, rats were sacrificed and dissected. A portion of the liver was rinsed in saline solution and quickly fixed in formalin (10\%) for microscopic evaluation. The specimens were then stained with haematoxylin and eosin ( $\mathrm{H}$ and $\mathrm{E})$ and subjected to histopathological analysis [31].

\subsubsection{Anti-Inflammatory Activity: Carrageenan-Induced Paw Edema}

Four groups of rats ( 6 rats each) were fasted for $12 \mathrm{~h}$. The control group (I) received normal saline. Group II received the reference compound indomethacin $(10 \mathrm{mg} / \mathrm{kg}$, p.o.). Groups III and IV obtained the extract (100 and $200 \mathrm{mg} / \mathrm{kg}$, respectively). After $1 \mathrm{~h}$, inflammation was inducted into the sub-planter region of the left hind paws of the animals using a carrageenan suspension $(0.1 \mathrm{~mL}$ of $1 \%$ $w / v$ suspension in $0.9 \%$ saline solution) [47]. After $4 \mathrm{~h}$, visible redness and pronounced swelling had developed and lasted for $48 \mathrm{~h}$. Initially, the paw volume was measured before and 1, 2, 3, and $4 \mathrm{~h}$ after carrageenan injection using a planimeter [48]. The change in edema volume for the corresponding time was calculated based on the difference between initial and subsequent readings. Anti-inflammatory activities were determined by comparison with the control group. Edema volumes were used to calculate $(\%)$ change in edema volume by using the following formula:

$\%$ change in edema volume $=($ edema volume after carrageenan injection - initial volume $/$ initial volume $) \times 100$

\subsubsection{Anti-Ulcer Activity: Ethanol-Induced Gastric Ulcer Model}

Rats were divided into 4 groups ( $n=6$ ). Group I (control group) received normal saline. Group II (ranitidine group) received ranitidine $(50 \mathrm{mg} / \mathrm{kg}$ in $1 \%$ tween 80$)$. Groups III and IV received methanol extract (100 and $200 \mathrm{mg} / \mathrm{kg}$, respectively). Intragastric administration of absolute ethanol was used to induce acute erosion of the gastric mucosa in fasting rats [49]. After $1 \mathrm{~h}$ of ethanol administration, animals were sacrificed by cervical dislocation. The stomachs were then excised along the greater curvature and examined macroscopically for mucosal necrotic lesions, red streaks, and red erosions [50]. The total lesion number was counted and lesion severity was recorded [51].

\section{Statistical Analysis}

Biological data are stated as mean \pm SE $(n=6)$ and analyzed statistically by one-way ANOVA followed by Tukey's post hoc test and Student's $t$-test, which were used to state the differences between the groups' tests using GraphPad Prism 5.0 (GraphPad Prism Software Inc., San Diego, CA, USA). The statistical significance was considered as $p<0.05$. Lesion numbers and severity were analyzed by Kruskal-Wallis non-parametric one-way ANOVA followed by the Mann Whitney multiple comparison test.

\section{Conclusions}

We isolated 13 known secondary metabolites, along with a new flavonoid robinobioside, gossypetin-3-O- $\beta$-D-robinobioside, from the leaf extract of $C$. gilliesii. The studied extract demonstrated 
substantial hepatoprotective, anti-inflammatory, and anti-ulcer activities in animals. Caesalpinia gilliesii is a good candidate for scavenging free radicals and counteracting oxidative stress, which can occur during liver and stomach injuries. Further studies are needed to explore the modes of action of the extract.

Supplementary Materials: The following are available online. Figure S1: UV spectrum of gossypetin-3-O- $\beta$-Drobinobioside [rhamnosyl $(1 \rightarrow 6)$ galactoside]; Figure S2: 1 H-NMR spectrum of gossypetin-3-O- $\beta$-D-robinobioside [rhamnosyl $(1 \rightarrow 6)$ galactoside]; Figure S3: HH-COSY NMR spectrum of gossypetin-3-O- $\beta$-D-robinobioside [rhamnosyl $(1 \rightarrow 6)$ galactoside]; Figure S4: APT-NMR spectrum of gossypetin-3-O- $\beta$-D-robinobioside [rhamnosyl $(1 \rightarrow 6)$ galactoside]; Figure S5: HSQC-NMR spectrum of gossypetin-3-O- $\beta$-D-robinobioside [rhamnosyl $(1 \rightarrow 6)$ galactoside]; Figure S6: HMBC-NMR spectrum of gossypetin-3-O- $\beta$-D-robinobioside [rhamnosyl $(1 \rightarrow 6)$ galactoside]; Figure S7: HPLC-PDA profile of the methanol extract of Caesalpinia gilliesii.

Author Contributions: M.E. performed the extraction, fractionation, isolation and characterization of the compounds, hepatoprotective activities and drafted the manuscript. M.A.E.-A. participated in the identification of the compounds, drafted the manuscript and designed the study. A.E.E.H. performed the extraction, hepatoprotective activities, and drafted the manuscript. S.E.A. performed antiulcer and anti-inflammatory activities. A.-G.M.R and M.A.E.R analyzed the data and conceived the study. M.S. performed MS analysis, analyzed the data and drafted the manuscript. S.M.O. performed the hepatoprotective activities, analyzed the data and conceived and designed the project. M.W. revised the manuscript and conceived and designed the project.

Funding: This work was supported by National Research Centre (NRC, Ph.D. fund no. 2/4/5). The authors received financial support from the Deutsche Forschungsgemeinschaft and Ruprecht-Karls-Universität Heidelberg within the funding program Open Access Publishing.

Conflicts of Interest: There are no conflicts of interest.

\section{References}

1. Kaplowitz, N. Idiosyncratic drug hepatotoxicity. Nat. Rev. Drug Discov. 2005, 4, 489. [CrossRef] [PubMed]

2. Pandit, A.; Sachdeva, T.; Bafna, P. Drug-induced hepatotoxicity: A review. J. Appl. Pharm. Sci. 2012, 2, 233-243. [CrossRef]

3. Rubenstein, J.H.; Laine, L. Systematic review: The hepatotoxicity of non-steroidal anti-inflammatory drugs. Aliment. Pharmacol. Ther. 2004, 20, 373-380. [CrossRef] [PubMed]

4. Schellack, N.; Fourie, J. A review of nonsteroidal anti-inflammatory drugs. SA Pharm. J. 2015, 82, 8-18.

5. Van Wyk, B.-E.; Wink, M. Phytomedicines, Herbal Drugs, and Poisons; University of Chicago Press: Chicago, IL, USA, 2015.

6. Mabberley, D.J. Mabberley's Plant-Book: A Portable Dictionary of Plants, Their Classifications and Uses; Cambridge University Press: Cambridge, UK, 2008.

7. Saeed, M.A.; Sabir, A. Antibacterial activity of Caesalpinia bonducella seeds. Fitoterapia 2001, 72, 807-809. [CrossRef]

8. Nakamura, E.S.; Kurosaki, F.; Arisawa, M.; Mukainaka, T.; Okuda, M.; Tokuda, H.; Nishino, H.; Pastore, F. Cancer chemopreventive effects of constituents of Caesalpinia ferrea and related compounds. Cancer Lett. 2002, 177, 119-124. [CrossRef]

9. Saenjum, C.; Chaiyasut, C.; Kadchumsang, S.; Chansakaow, S.; Suttajit, M. Antioxidant activity and protective effects on DNA damage of Caesalpinia sappan L. extract. J. Med. Plants Res. 2010, 4, 1594-1608.

10. Shukla, S.; Mehta, A.; John, J.; Singh, S.; Mehta, P.; Vyas, S.P. Antioxidant activity and total phenolic content of ethanolic extract of Caesalpinia bonducella seeds. Food Chem. Toxicol. 2009, 47, 1848-1851. [CrossRef]

11. Osman, S.M.; El-Haddad, A.E.; El-Raey, M.A.; El-Khalik, S.M.A.; Koheil, M.A.; Wink, M. A new octadecenoic acid derivative from Caesalpinia gilliesii flowers with potent hepatoprotective activity. Pharmacog. Mag. 2016, $12, \mathrm{~S} 332$.

12. Ulubelen, A.; McCaughey, W.; Cole, J. Proteinaceous antitumor substances from plants III. Caesalpinia gilliesii (Leguminosae). J. Pharm. Sci. 1967, 56, 914-916. [CrossRef]

13. Mabry, T.J.; Markham, K.; Thomas, M. The Systematic Identification of Flavonoids; Springer: New York, NY, USA, 1970.

14. Markham, K.R.; Chari, V.M. Carbon-13 NMR Spectroscopy of Flavonoids, in the Flavonoids; Springer: New York, NY, USA, 1982; pp. 19-134.

15. Harbone, J.; Mabry, T. The Flavonoids: Advances in Research; Chapman and Hall: New York, NY, USA, 1982. 
16. Agrawal, P. Flavonoid glycosides. In Carbon-13 NMR of Flavonoids; Elsevier: Amsterdam, The Netherlands, 1989.

17. Nawwar, M.A.; Buddrus, J. A gossypetin glucuronide sulphate from the leaves of Malva sylvestris. Phytochemistry 1981, 20, 2446-2448. [CrossRef]

18. Bennini, B.; Chulia, A.J.; Kaouadji, M. Flavonol glycosides from Erica cinerea. J. Nat. Prod. 1994, 57, $178-180$. [CrossRef]

19. Harborne, J. Phytochemical Methods; Chapman and Hall: New York, NY, USA, 1984; Volume 3, pp. $100-117$.

20. Teles, Y.C.; Ribeiro-Filho, J.; Bozza, P.T.; Agra, M.d.F.; Siheri, W.; Igoli, J.O.; Gray, A.I.; Souza, M.d.F.V.d. Phenolic constituents from Wissadula periplocifolia (L.) C. Presl. and anti-inflammatory activity of 7, 4'-di-O-methylisoscutellarein. Nat. Prod. Res. 2016, 30, 1880-1884. [CrossRef] [PubMed]

21. Hussein, S.A.; El-Mesallamy, A.M.; Souleman, A.M.; Mousa, M.A. Cytotoxic activity of bioactive compound from Caesalpinia ferrea Martius, Fabaceae. Int. J. Pharmacog. Phytochem. Res. 2016, 8, 2080-2084.

22. N'guessan, J.; Bidié, A.; Lenta, B.; Weniger, B.; Andre, P.; Guédé-Guina, F. In vitro assays for bioactivity-guided isolation of antisalmonella and antioxidant compounds in Thonningia sanguinea flowers. Afr. J. Biotechnol. 2007, 6, 1685-1689.

23. Panda, S.; Chowdary, P. Synthesis of novel indolyl-pyrimidine antiinflammatory, antioxidant and antibacterial agents. Ind. J. Pharm. Sci. 2008, 70, 208-213. [CrossRef] [PubMed]

24. Duwiejua, M.; Zeitlin, I.; Waterman, P.; Chapman, J.; Mhango, G.; Provan, G. Anti-inflammatory activity of resins from some species of the plant family Burseraceae. Planta Med. 1993, 59, 12-16. [CrossRef]

25. Waldum, H.; Arnestad, J.; Brenna, E.; Eide, I.; Syversen, U.; Sandvik, A. Marked increase in gastric acid secretory capacity after omeprazole treatment. Gut 1996, 39, 649-653. [CrossRef]

26. Hussaini, J.; Nazmul, M.; Abdullah, M.; Ismail, S. Recombinant Clone ABA392 Protects laboratory animals from Pasteurella multocida serotype B. J. Vet. Adv. 2012, 2, 114-119.

27. Wei, X.-H.; Yang, S.-J.; Liang, N.; Hu, D.-Y.; Jin, L.-H.; Xue, W.; Yang, S. Chemical constituents of Caesalpinia decapetala (Roth) Alston. Molecules 2013, 18, 1325-1336. [CrossRef]

28. Wu, M.; Wang, Y.F.; Zhang, M.L.; Huo, C.H.; Dong, M.; Shi, Q.W.; Kiyota, H. Chemical constituents of plants from the genus Caesalpinia. Chem. Biodiv. 2011, 8, 1370-1399. [CrossRef]

29. Ogunlana, O.O.; Ogunlana, O. Antiplasmodial flavonoid from young twigs and leaves of Caesalpinia bonduc (Linn) Roxb. J. Chem. Pharm. Res. 2015, 7, 931-937.

30. Osman, S.M.; Khalek, S.M.A.; Koheil, M.A.; El-Haddad, A.E.; Wink, M. A new steroidal compound ( $\beta$-sitosterol-3-O-butyl) isolated from Caesalpinia gilliesii flowers. IJARNP 2015, 8, 14-19.

31. Sobeh, M.; Esmat, A.; Petruk, G.; Abdelfattah, M.A.O.; Dmirieh, M.; Monti, D.M.; Abdel-Naim, A.B.; Wink, M. Phenolic compounds from Syzygium jambos (Myrtaceae) exhibit distinct antioxidant and hepatoprotective activities in vivo. J. Funct. Food 2018, 41, 223-231. [CrossRef]

32. Sarkar, R.; Hazra, B.; Mandal, N. Hepatoprotective potential of Caesalpinia crista against iron-overloadinduced liver toxicity in mice. Evid. Based Complement. Altern. Med. 2012, 2012. [CrossRef] [PubMed]

33. Zanin, J.L.B.; De Carvalho, B.A.; Salles Martineli, P.; Dos Santos, M.H.; Lago, J.H.G.; Sartorelli, P.; Viegas, C.; Soares, M.G. The genus Caesalpinia L. (Caesalpiniaceae): Phytochemical and pharmacological characteristics. Molecules 2012, 17, 7887-7902. [CrossRef] [PubMed]

34. Sobeh, M.; Mahmoud, M.F.; Petruk, G.; Rezq, S.; Ashour, M.L.; Youssef, F.S.; El-Shazly, A.M.; Monti, D.M.; Abdel-Naim, A.B.; Wink, M. Syzygium aqueum: A polyphenol- rich leaf extract exhibits antioxidant, hepatoprotective, pain-killing and anti-inflammatory activities in animal models. Front Pharmacol. 2018, 9. [CrossRef]

35. Tapas, A.R.; Sakarkar, D.; Kakde, R. Flavonoids as nutraceuticals: A review. Trop J. Pharm. Res. 2008, 7, 1089-1099. [CrossRef]

36. Kumar, S.; Pandey, A.K. Chemistry and biological activities of flavonoids: An overview. Sci. World. J. 2013. [CrossRef]

37. Rao, Y.K.; Fang, S.-H.; Tzeng, Y.-M. Anti-inflammatory activities of flavonoids isolated from Caesalpinia pulcherrima. J. Ethnopharmacol. 2005, 100, 249-253. [CrossRef]

38. Ribeiro, A.R.S.; Diniz, P.B.F.; Estevam, C.S.; Pinheiro, M.S.; Albuquerque-Júnior, R.L.C.; Thomazzi, S.M. Gastroprotective activity of the ethanol extract from the inner bark of Caesalpinia pyramidalis in rats. J. Ethnopharmacol. 2013, 147, 383-388. [CrossRef] [PubMed] 
39. Sumalatha, S.; Padma, D.; Pai, K.S.R.; Kotian, S.R.; Kumar, N.; Bhat, K.M. Hepatoprotective activity of aqueous extract of Caesalpinia bonduc against CCl4 induced chronic hepatotoxicity. Int. J. Pharm. Pharm. Sci. 2016, 8, 207-211.

40. Hikino, H.; Taguchi, T.; Fujimura, H.; Hiramatsu, Y. Antiinflammatory principles of Caesalpinia sappan wood and of Haematoxylon campechianum wood1. Planta Med. 1977, 31, 214-220. [CrossRef] [PubMed]

41. Youssef, F.S.; Ashour, M.L.; Sobeh, M.; El-Beshbishy, H.A.; Singab, A.N.; Wink, M. Eremophila maculata-Isolation of a rare naturally-occurring lignan glycoside and the hepatoprotective activity of the leaf extract. Phytomedicine 2016, 23, 1484-1493. [CrossRef] [PubMed]

42. Sobeh, M.; Youssef, F.S.; Esmat, A.; Petruk, G.; El-Khatib, A.H.; Monti, D.M.; Ashour, M.L.; Wink, M. High resolution UPLC-MS/MS profiling of polyphenolics in the methanol extract of Syzygium samarangense leaves and its hepatoprotective activity in rats with $\mathrm{CCl}_{4}$-induced hepatic damage. Food Chem. Toxicol. 2018, 113, 145-153. [CrossRef] [PubMed]

43. Emam, M.; El Raey, M.A.; Eisa, W.H.; El-Haddad, A.E.; Osman, S.M.; El-Ansari, M.A.; Rabie, A.-G.M. Green synthesis of silver nanoparticles from Caesalpiniagilliesii (Hook) leaves: Antimicrobial activity and in vitro cytotoxic effect against BJ-1 and MCF-7 cells. J. App. Pharm. Sci. 2017, 7, 226-233.

44. Sobeh, M.; Mahmoud, M.F.; Abdelfattah, M.A.O.; El-Beshbishy, H.A.; El-Shazly, A.M.; Wink, M. Albizia harveyi: Phytochemical profiling, antioxidant, antidiabetic and hepatoprotective activities of the bark extract. Med. Chem. Res. 2017, 26, 3091-3105. [CrossRef]

45. Galighor, A.; Kozloff, E. Essentials of Practical Microtechnique, 2nd ed.; Lea and Febiger: NewYork, NY, USA, 1976.

46. Benzie, I.F.; Strain, J.J. The ferric reducing ability of plasma (FRAP) as a measure of "antioxidant power": The FRAP assay. Anal. Biochem. 1996, 239, 70-76. [CrossRef]

47. Winter, C.A.; Risley, E.A.; Nuss, G.W. Carrageenan-induced edema in hind paw of the rat as an assay for antiinflammatory drugs. Proc. Society Exp. Biol. Med. 1962, 111, 544-547. [CrossRef]

48. Chattopadhyay, D.; Arunachalam, G.; Mandal, A.B.; Sur, T.K.; Mandal, S.C.; Bhattacharya, S. Antimicrobial and anti-inflammatory activity of folklore: Mallotus peltatus leaf extract. J. Ethnopharmacol. 2002, 82, $229-237$. [CrossRef]

49. Robert, A.; Nezamis, J.E.; Lancaster, C.; Hanchar, A.J. Cytoprotection by prostaglandins in rats: Prevention of gastric necrosis produced by alcohol, $\mathrm{HCl}, \mathrm{NaOH}$, hypertonic $\mathrm{NaCl}$, and thermal injury. Gastroenterol $1979,77,433-443$.

50. Mózsik, G.; Moron, F.; Jávor, T. Cellular mechanisms of the development of gastric mucosal damage and of gastrocytoprotection induced by prostacyclin in rats. A pharmacological study. Prostag. Leukotr. Med. 1982, 9, 71-84. [CrossRef]

51. Ibrahim, B.M.; Salama, A.A.; Abdallah, H.M.; El Awdan, S.A.; Shaffie, N.M. Study of the protective effects of flaxseed oil on ethanol induced gastric mucosal lesions in non ovariectomized and ovariectomized rats. Int. J. Pharmacol. 2016, 12, 329-339. [CrossRef]

Sample Availability: Samples of the compounds and the plant material are available from the authors.

(C) 2018 by the authors. Licensee MDPI, Basel, Switzerland. This article is an open access article distributed under the terms and conditions of the Creative Commons Attribution (CC BY) license (http:/ / creativecommons.org/licenses/by/4.0/). 